Article

\title{
Enforcing Your Own Human Rights? The Role of Social Norms in Compliance with Human Rights Treaties
}

\author{
Violet Benneker ${ }^{1}$, Klarita Gërxhani ${ }^{2}$ and Stephanie Steinmetz ${ }^{3, *}$ \\ ${ }^{1}$ Institute of Political Science, Leiden University, 2300 RB Leiden, The Netherlands, E-Mail: v.l.benneker@fsw.leidenuniv.nl \\ 2 Department of Political and Social Sciences, European University Institute, 50014 San Domenico di Fiesole, Italy; \\ E-Mail: klarita.gerxhani@eui.eu \\ ${ }^{3}$ Institute for Social Sciences, University of Lausanne, 1015 Lausanne, Switzerland; E-Mail: stephanie.steinmetz@unil.ch \\ * Corresponding author
}

Submitted: 1 April 2019 | Accepted: 17 January 2020 | Published: 20 March 2020

\begin{abstract}
Although scholars are increasingly able to explain why states (do not) comply with human rights treaties, the role of social norms in compliance has been neglected. This is remarkable because human rights often directly address social norms. Our study aims to contribute to the existing literature by providing quantitative and qualitative evidence on the relationship between citizens' social norms and compliance with human rights treaties. The quantitative results provide strong support for such a relationship. The findings from the additional qualitative analysis suggest that bargaining over (and thus changing) social norms is an important process through which compliance with human rights can be influenced.
\end{abstract}

\section{Keywords}

bargaining approach; compliance; human rights; human rights treaties; social norms

Issue

This article is part of the issue "Institutions of Inclusion and Exclusion" edited by J. Cok Vrooman (Utrecht University and The Netherlands Institute for Social Research|SCP, the Netherlands) and Marcel Coenders (Utrecht University and The Netherlands Institute for Social Research|SCP, the Netherlands).

(C) 2020 by the authors; licensee Cogitatio (Lisbon, Portugal). This article is licensed under a Creative Commons Attribution 4.0 International License (CC BY).

\section{Introduction}

The implementation of human rights treaties is a critical aim of some states and many international organizations. However, the ratification of a human rights treaty is not enough to ensure its effectiveness. Despite extensive scholarly attention, the explanation for the large variety in states' human rights practices remains unsatisfactory. Concepts such as decoupling clarify why a state ratifies human rights treaties, but fail to explain the different and changing levels of compliance. Scholars are therefore increasingly focusing on domestic institutions to explain states' human rights practices.

This article is built on the proposition that the domestic turn in human rights studies is pivotal for a better understanding of the variations in compliance we see across the world. We argue, however, that this turn has neglected the vital role of informal institutions in shaping states' behavior (Cortell \& Davis, 2000; Fraser, 2019; Harris-Short, 2003; Zwart, 2012; Zwingel, 2012). We hypothesize that populations resist the implementation of human rights when their provisions do not match social norms, and are supportive of implementation when provisions do match norms. A match could then increase the effectiveness of human rights treaties. Importantly, this hypothesis suggests that citizens themselves have an important role to play in both the protection and violation of their own rights. Our study aims to contribute to the existing literature by providing quantitative and qualitative evidence concerning the relationship between citizens' social norms and compliance with human rights treaties. 
The following question guides the research: What is the role of populations' social norms in state compliance with human rights treaties? We focus specifically on Article 7 of the Convention on the Elimination of all forms of Discrimination Against Women (CEDAW), which covers women's active and passive voting rights. We apply a mixed-methods design that includes a quantitative empirical test on the association between social norms and state compliance. The additional qualitative approach enforces our understanding of which processes might drive the observed relationship. A country-by-year data set was created from several international data sources covering seventy-four countries. The complementary qualitative case study focuses on the Netherlands, a country characterized by a high level of compliance and progressive norms. Looking in greater depth at this case gives insights into how processes of social norm change can support compliance.

\section{Theoretical Background}

Already twenty years ago, Andrew Cortell and James Davis urged for further research on populations' traditions and preferences, as these could potentially explain cross-national variation in compliance (Cortell \& Davis, 2000, pp. 66-67). They argued that a convention would automatically have the status of a national norm, when there is a cultural match between the international convention and domestic traditions. This could also possibly increase the level of compliance. Conversely, in case of a mismatch, the population would consider the treaty to be inconsistent with their own values, traditions, or aspirations. The promotion of such an international convention might then lead to domestic resistance and its rejection (Bloomfield, 2015; Cortell \& Davis, 2000). In this case, a state might provide all the legal guarantees that an international treaty requires, but conflicting domestic traditions and practices could still hinder their effective use (Fraser, 2019; Merry, 2009; Welzel, 2002; Zwingel, 2012). Similarly, in her valuable study, Sonia Harris-Short (2003, p. 134) suggests that in many cases "the state finds itself unable to realize [its human rights commitment] in practice, because of the absence of a human rights culture at the local level." She argues that the problem of non-compliance cannot always be blamed on state elites who are unwilling to comply. On the contrary, even if there is political will to comply with human rights, the reality on the ground can make compliance difficult. Nine years after Harris-Short's study, Tom Zwart (2012, p. 561) again emphasized the importance of considering local practices for understanding the implementation of human rights. He states that human rights implementations "that add to the existing [local] arrangements stand a far better chance of being supported and carried out by the community than those that are enforced topdown." Julie Fraser (2019, p. 977) further elaborates on this point, by arguing that in many situations, social institutions "can be more potent than legislation" in improv- ing human rights implementation. She advocates using more culturally sensitive approaches to implement human rights, by making active use of and building on social institutions (Fraser, 2019, p. 977).

Yet, despite this elaborate attention, the discussion on the role of norms remains unsettled. Zwart (2012) and Ibhawoh (2000), despite providing pivotal insights on the role of local practices, present limited empirical evidence. In fact, both quantitative and qualitative scholars campaign for more empirical analysis that legal research cannot provide. Harris-Short (2003) and Fraser (2019) both present relevant and interesting empirical evidence in their case studies, thereby demonstrating the need for more empirical evidence beyond their single cases. Moreover, Harris-Short's study highlights the need for more empirical data on social norms, as her evidence is based on documents created by state elites. As she herself acknowledges, governments might not be the most reliable interpreters of a population's cultural values (Harris-Short, 2003). Thus, although valuable, her study lacks the type of evidence that only data collected at the level of citizens can provide. In this article, we make an attempt to provide such evidence by presenting cross-country quantitative survey data that test the association between social norms and compliance, as well as qualitative evidence from a case study that demonstrates how changing social norms can drive compliance.

\subsection{Social Norms}

The limited evidence is partly related to a disagreement on what social norms are. It appears that scholars providing empirical evidence do not study norms within populations directly. Instead, they focus on, for instance, domestic policies (Simmons, 2009), constituencies (Dai, 2005), or local redefinitions of international conventions (Acharya, 2004; An-Na'im, 2000; Merry, 2009; Zwingel, 2012). Other analyses do not clearly distinguish between populations' social norms, i.e., informal institutions guiding people's interactions, and national formal rules, such as laws, i.e., formal institutions (Flowers, 2009).

Drawing on insights from new institutionalism, this article aims to advance the existing knowledge of social norms and human rights compliance by providing empirical evidence that is based on a clear definition and operationalization of social norms within populations. We consider institutions, both formal and informal, to present a web of interrelated norms or rules that govern social relationships. It is through facilitating and/or constraining that these institutions give shape to larger unit performance, such as families, work environments, and even entire economies (Gërxhani, 2004, p. 732; Nee \& Ingram, 1998 , p. 19). Formal institutions are explicit rules, such as laws, which rely on formal monitoring mechanisms from authorities such as the state. In contrast, informal institutions, i.e., social norms, are the informal rules of a group or community. Shared understandings of a social group or community on gender (in-)equality are cases in 
point. These norms are not necessarily explicitly stated, and rely on informal mechanisms of monitoring, such as social (dis)approval (Nee \& Ingram, 1998, p. 19).

New institutionalist research has shown that studying the relationship between social norms and formal rules is pivotal in understanding political (Helmke \& Levitsky, 2004), economic (Gërxhani, 2004), and legal outcomes (Moon \& Hein, 2013). Since human rights treaties are formal rules, insights from new institutionalism can also be relevant to further understanding the relationship between social norms and compliance with these treaties. The literature recognizes four types of interactions between formal and informal institutions (Helmke \& Levitsky, 2004). The first is complementarity, in which informal rules or social norms coexist with effective formal institutions. In such an interaction, social norms play a crucial complementary role in making the formal rules effective, ensuring that they are not only rules on paper. One example is the U.S. Constitution. Its effectiveness is often linked to a complementary set of shared beliefs and expectations among citizens (Helmke \& Levitsky, 2004, p. 728). The second type of interaction is accommodation, in which social norms provide incentives that support a different type of behaviour than the formal institutions do. Yet, as the formal institutions are effective, the informal norms simply accommodate them by providing alternatives and do not constitute a direct challenge to the formal rules. One classic example regards the former communist countries where the strictly enforced formal rules were accommodated by informal arrangements of goods provision. The third type of interaction is competition, in which formal rules are weakly enforced and typically not adhered to. In this case, social norms can become dominant and offer a competing role to formal rules in shaping behaviour. Such an interaction is observed in southern Italy where norms enforced by the Mafia are dominant. Finally, the fourth type of interaction is substitution. Here, the formal institutions are weakly enforced as well. However, social norms take a substituting role by establishing expectations and guiding behavior in the same way the weak formal rules were designed to do (Helmke \& Levitsky, 2004, p. 729).

The latter case, in which the interaction between formal rules and social norms is substitutive, is particularly interesting when it comes to human rights. Human rights enforcement mechanisms are generally considered as lacking teeth; states are not routinely or consistently held accountable for ongoing violations (Hafner-Burton \& Tsutui, 2005, 2007; Lebovic \& Voeten, 2009, p. 79). We argue that individuals and communities can succeed in substituting weakly enforced formal human rights through their ability to enforce these rights informally, and subsequently change social norms. Informal norms within societies are never static. They often differ among communities within one society, and are subject to constant struggle and change (Donnelly, 2007). We apply the so-called bargaining approach within new institutionalism to explain whether and how such change of so- cial norms in communities happens. This approach is important as it provides a possible explanation of how negotiating over (and thus changing) social norms affects state compliance with international conventions. Moreover, it responds to earlier calls to focus more on social norms, as well as using a more actor-based approach to understand human rights compliance (Fraser, 2019; Nyamu-Musembi, 2002). As Celestine Nyamu-Musembi (2002, p. 1) argues, "rights are shaped through actual struggles informed by people's own understanding of what they are justly entitled to."

The bargaining approach outlines how those with the most bargaining power are most likely to see their preferred norm established as a common norm in their community (Knight \& Ensminger, 1998). The basis of this bargaining power can be material, such as financial resources, or non-material, such as ideology and status. An important element of bargaining power is access to or control over formal and informal enforcement mechanisms. This is because even when a new norm is introduced and shared within a population, it is essential that the initiators of norm change establish and use effective sanctioning mechanisms. Otherwise, the new norm may not be adhered to, and people can return to their old practices (Knight \& Ensminger, 1998, p. 120).

In conclusion, by drawing on insights from new institutionalism this study will quantitatively test the relationship between social norms and compliance based on the following proposition: The higher the percentage of people adhering to social norms that contradict the content of a human rights treaty, the lower will be the level of compliance with that treaty. However, such a quantitative relationship does not say anything about the underlying process driving the association between social norms and compliance with a treaty. We therefore use qualitative methods to shed more light on this process and to better interpret the findings in the framework of the bargaining approach within new institutionalism.

\section{Study Design, Data, and Methods}

Our empirical focus is on the CEDAW. This choice is motivated by our main interest in exploring the relationship between social norms and compliance. Women's rights are often deeply rooted in local cultures. Even governments that genuinely want to improve women's rights are expected to see their goals obstructed by social norms regarding women (Ibhawoh, 2000, p. 848; Merry, 2009; Simmons, 2009, p. 203). We thus expect the impact of social norms on compliance to be the strongest for this treaty. In other words, if we find no relationship between social norms and compliance with the contested CEDAW, it may even be less likely to find it for more consensual treaties. This strategy is known as choosing the most likely observation. The disadvantage is that it is not the most rigorous test, because the treaties for which the effect of norms is less likely, such as the Convention Against Torture, have not been tested. 
Nonetheless, the findings may be worthy of further investigation, as the relationship will have survived a plausibility probe (King, Keohane, \& Verba, 1994).

We specifically narrow to one treaty article, namely Article 7A, for two reasons. First, it is very difficult to measure compliance with the CEDAW as a whole. The treaty contains broad obligations that are difficult to define precisely. This is usually solved by focusing on the basic rights that are mentioned most explicitly in the treaty (Hathaway, 2002; Simmons, 2009, p. 255). Article 7A, which deals with political participation, is a case in point:

State Parties shall take all appropriate measures to eliminate discrimination against women in the political and public life of the country and, in particular, shall ensure to women, on equal terms with men, the right: (a) To vote in all elections and public referenda and to be eligible for election to all publicly elected bodies. (United Nations General Assembly, 1979)

The second reason to narrow to Article 7 is because it is considered to be "a fundamental provision of the Convention, the implementation of which is essential to fulfilling its object and purpose" (Government of Finland, 1996) by many ratifying states. Nonetheless, we do not aim to generalize our findings to the whole treaty as it is possible that the relationship between social norms and compliance is different for separate articles of the CEDAW. As we do not provide empirical evidence for the other articles, that could be a focus for future research to explore.

\subsection{Quantitative Data and Methods}

We created a data set of 123 country-year observations covering 73 countries. Each country was assigned several country-years when it had several measure points over time. The number of country-years is determined by data availability from the World Values Survey and from the augmented macro-level data (see Section A for selection of countries in the Supplementary Material). The time period ranges from 1995 to 2008 . There is a maximum of three measure points per country (1996, 2001, and 2007). The sample creates an unbalanced panel, because not every country is measured in every survey wave. Countries that have not ratified the CEDAW are excluded from the sample.

The dependent variable measures the effectiveness of Article 7A through the percentage of seats in national parliaments held by women. This indicator suffers from the same issue as many compliance indicators, as there is a misfit between our actual data and the precise requirements of the treaty (Hathaway, 2002, p. 1968). Yet, we believe this measure is appropriate, first, because it is more specific than other indicators. For example, the Gender Inequality Index is an often-used indicator, but it is too broad for our purposes. It includes reproductive health, percentage of parliamentary seats, and labour market participation in one single indicator. Second, the percentage of parliamentary seats is a highly reliable indicator. It is measured in the same way all over the world and has no sampling errors or reporting bias. Finally, also in other literature on women's political participation, this indicator is considered "strongly indicative of the success of countries in putting in place practices and institutions to achieve the requirements" (Hathaway, 2002, p. 1968).

The central independent variable is a measure of social norms regarding women in politics ("conservatism"). For this variable, we use a statement from the World Values Survey (three waves, from 1995 until 2007), which directly measures norms (i.e., shared beliefs) regarding women in political life: "On the whole, men make better political leaders than women do" (Inglehart et al., 2014). The original four-point scale was recoded such that a respondent either agrees or disagrees with this statement. The answers were then aggregated to percentages at the country level. Thus, a higher score on "conservatism" means a larger percentage of people per country agree that men make better political leaders than women do. We are aware that such an aggregated measure of social norms, which is a highly complex and multifaceted concept, is overly simplified. However, it does account for the critique that populations cannot be treated as homogeneous groups with no internal differentiation (Donnelly, 2007). Because it is measured in percentages, the variable accounts for such differentiation and does not treat the population as a homogeneous unit. We also control for several variables which were selected based on previous studies on compliance with human rights (Cole, 2015; Hathaway, 2007; see Section B in the Supplementary Material).

We apply a time lag of five years between the independent variable (and controls) and the dependent variable. We do so because if, at one point in time, social norms are indeed related to the percentage of women in national parliaments, we could expect to see some of that influence in a following leadership change. When there was no data available for the dependent variable in a specific year, data from the following or the previous year was used. In some cases, it was necessary to expand this to two years. For education, this was in some highly exceptional cases still not possible. Therefore, a maximum of nine years following or previous to the year, for which data was lacking, is used. Although nine years is a considerable time span, it is not expected that the level of education in a country will change significantly that quickly.

A multi-level regression analysis is used to explore the relationship between social norms and state compliance across countries controlling for changes over time. We are also able to explore whether or not the relationship is consistent across countries. We run four different models (M1-M4) including variables in a stepwise procedure. $\mathrm{M} 1$ is an empty model which examines how much variation in compliance can be attributed to between-country variation. M2 tests the impact of the control variables, whereas M3 includes the social norm measure as the main independent variable. M4 repli- 
cates M3 but additionally includes a random slope for the social norm measure in order to see whether the relationship between social norms and compliance varies across countries.

\subsection{Qualitative Data and Methods}

For the qualitative analysis, we looked for a country where social norms support compliance, as this enables a study of the underlying process. Based on an explorative analysis of one wave of the World Value Survey augmented with data of the World Bank, we identified a group of four countries with a large fraction of female representatives and a low percentage of respondents agreeing that men are better political leaders than women. This group consists of Sweden, Norway, Finland and the Netherlands (see Section A in the Supplementary Material).

From this group, we selected the Netherlands, first because of its reputation for being a progressive country with extensive women's rights and emancipation (Boerefijn \& Goldschmidt, 2007). Second, and equally important, the Dutch parliament houses a party called Staatkundig Gereformeerde Partij (SGP; Reformed Party), which persistently excluded women from party membership and electable positions. This led to repeated critique by the CEDAW Committee, which concluded that the Netherlands was in violation of the treaty. Nevertheless, the Dutch Government refused to interfere in the party's affairs, and the party itself dismissed the Committee's comments. The party's constituency also preferred the status quo (Oomen, Guijt, \& Ploeg, 2010). It was therefore all the more surprising that a woman should run for election for the SGP in 2013. She subsequently became the first female SGP city council representative. What happened, and how?

To answer this question, we conducted twelve indepth semi-structured interviews and content analysis of media sources. Ten interviews were held with active SGP members, including the female representative herself, and two with experts on Dutch CEDAW compliance. All interviews took place between January and April 2014. The interviews were coded and analysed using ATLAS.ti. The content analysis is based on three different media sources, and provides additional contextual understanding of the respondents' statements and illustrates their experiences (for details on the selection of respondents and the qualitative data, see Section $C$ in the Supplementary Material).

\section{Quantitative Evidence}

Detailed multi-level regression results are presented in Section D in the Supplementary Material, Table 1. Here, we discuss the main conclusions. Starting with the question, how much variation in state compliance can be attributed to within or across country variation, M1 shows that actually $90 \%$ of the unexplained variance in state compliance can be found across countries and only $10 \%$ within countries over time. When adding control variables in $\mathrm{M} 2$, we can observe that $32.28 \%$ of the variance in state compliance at the country level can be explained.

The main model is M3, which examines the association between social norms and compliance including relevant control variables. The variable that captures the conservatism in social norms (that is, the extent to which people agree that men are better political leaders) has a coefficient of -0.19 (with a standard error of 0.05 ). This is significantly different from 0 with $p<0.001$. This negative association shows that the larger the share of a population adhering to conservative norms, the lower the compliance with the CEDAW. When adding the norm variable, the explained variance at the country level increases to $51.56 \%$. A likelihood-ratio (LR) test indicates that adding social norms as an explanatory variable significantly improves the model's explanatory power compared to $M 2(p<0.01)$.

Finally, M4 adds a random slope for norms ("conservatism") to see whether country differences exist in the association between norms and compliance. The results show little to no difference in comparison to $M 3$. An LR test confirms that adding the random slope to M3 does not significantly improve the explanatory power $(p>0.99)$. We can thus conclude that for our sample the association between norms and compliance seems to be consistent across countries.

In sum, our findings indicate that a population's social norms are significantly related to state compliance with Article 7A of the CEDAW, and that this effect is consistent across countries.

Given the fact that the presented estimates might be affected by influential cases (in this case countries), we also apply a robustness check in which we rerun the analyses excluding those countries which have been identified as influential (based on Cook's D, six countries have been excluded: Argentina, Bulgaria, Peru, Rwanda, South Africa, and Turkey). The results (see Table 2, Section D in the Supplementary Material) do not substantially change. The coefficient for norms ("conservatism") remains positive and significant and is slightly stronger than in the model including the influential cases.

\section{Qualitative Evidence}

Though very important, such quantitative findings tell us little about the processes that underlie the relationship between social norms and state compliance. For this purpose, we turn to the qualitative case study on the Netherlands. The Dutch generally support women taking up public functions; less than $20 \%$ agree that men are better political leaders. This progressive context has developed gradually over the years.

In contrast to this widespread acceptance of gender equality, there is one Dutch political party, the SGP, that excluded women from political office until recently. The party is the formal political organization of the community of orthodox reformed Christians in the 
Netherlands. This group makes up about $10 \%$ of all reformed Christians, which measure about two-and-a-half million people out of the total Dutch population of about seventeen million (Oomen et al., 2010, p. 162). According to the SGP community, a woman's calling is not politics, but taking care of her family. Many women in this community willingly disregard their voting and membership rights, as they believe these are not in line with women's Biblical calling (Oomen et al., 2010, p. 169). Although the SGP's so-called "women's stance" is not popular with the rest of the Dutch society (Oomen et al., 2010), the party has continually occupied two seats in the Dutch parliament of 150 seats. Unexpectedly though, a woman, Lilian Janse, became party leader of a local SGP branch in 2013 and was elected as SGP city council representative in 2014. In the following section, we will apply the bargaining approach of new institutionalism to investigate whether this change can be explained by a bargaining process over social norms concerning women in politics.

\subsection{Conflict of Interest}

A first precondition for a bargaining process on norms to occur is the existence of a conflict of interest between two groups within a community over the changing of a dominant norm, in our case the SGP's women's stance (Knight \& Ensminger, 1998). For religious-based ideological reasons, most SGP members did not want to accept women into politics (Oomen et al., 2010). Most of our interviewees argue that "we have a Bible which clearly states that God, from the creation of mankind onwards, really distinguished [between men and women]. And that is very valuable" (Respondent 10 ). For many years, this women's stance was regarded as the status quo within the SGP community.

The election of a female party leader in Vlissingen ( $a$ small harbour city in the South-West) meant a sudden break with the SGP community's norm. Two particular circumstances played a role. First, and most importantly, the Vlissingen branch could not find a willing male party leader for the elections, and were glad Lilian Janse was willing to take up the responsibility. Second, the branch was weakly represented in the council, and having a female candidate in the more emancipated Vlissingen was not likely to lead to a loss in votes-if anything, they might be able to win more votes than in previous rounds. This made a change in the branch's perception of the SGP's norm; women's political participation became more desirable than maintaining the status quo.

One can thus argue that a conflict of interest emerged within the SGP over its women's stance. The Vlissingen branch had interests in breaking with the old norm, while the national majority wished to uphold the traditional women's stance. At the same time, it must be emphasized that there was also considerable common ground between these seemingly opposed groups. All strongly believe that the Bible proposes a natural order, in which the man is seen as the leader of the fam- ily, and the woman, the main care-taker. The Vlissingen branch had no intention of changing that basic belief. The only issue at stake was what this basic belief meant for the role of women in politics. For the members in Vlissingen, a woman could participate in politics after finishing her main responsibilities in the family. In their view, the Bible does not state that it is not allowed. On the contrary, they felt the Bible clearly describes women who did participate in politics, taking the biblical figures such as the Queen of Sheba and Deborah as main examples (Respondent 4; Respondent 7).

\subsection{Asymmetry in Resources}

The second precondition for a bargaining process and possible change of norms is an asymmetry in bargaining resources between the two groups. An important resource is access to and control over norm enforcement methods. Informal methods of enforcement within a community concern rewards or social disapproval and ostracism (Knight \& Ensminger, 1998, p. 106). Formal methods of enforcement include access to or control over official bodies, and most notably, initiation of court cases.

Within the SGP community, strong informal disapproval on the women's stance seems to have been largely absent. Also those who did disagree with the women's stance had little intention of changing it, considering party and community unity more important. In this respect, it seems that the Vlissingen branch had very little informal bargaining power. A very different picture emerges, however, if one takes into account the way the rest of Dutch society frowned upon the SGP's women's stance. All the interviewed respondents speak of strong social disapproval against the SGP community by a majority of the Dutch population because of its women's stance. This disapproval is experienced on a regular basis:

If I tell them that I am on the candidates' list for the SGP, they compare you to the Taliban, who considers women to be less worthy than dogs. They do not give you a chance to really explain your position. (Respondent 10)

Most respondents consider such informal disapproval as condemnatory, and feel their norms clash with the rest of the Dutch society. Our media analysis confirms these experiences. Especially articles from the main left-wing newspaper tend to ridicule the SGP and its women's stance: "It's about a backward political party, we don't have to argue about that anymore" (Abraham, 2003). This conflict between the SGP and the large majority of the Dutch increased the bargaining power of the Vlissingen branch when proposing a new norm of women being electable, by supporting the candidacy of a firstever female party leader.

Informal bargaining power is only part of the story, however. Access to, or control over formal enforcement 
mechanisms can also be influential in the bargaining process. For those wanting to change the SGP's women's stance, these were plenty. Dutch law made it possible to sue the party, if only one SGP woman was willing to do so. And yet, no SGP member did-not even the Vlissingen branch. The women's stance was part of the official regulations of the party, and no one wanted to change these via the court (Oomen et al., 2010).

Again, as with the informal method of enforcement, formal enforcement came from outside the SGP. In 2003, a group of Dutch NGOs sued the Dutch State for violating women's rights. This immediately put a great deal of pressure on the SGP community: "I even considered this to be threatening now and then. Apparently, we are no longer granted any space...in the democratic Netherlands" (Respondent 11). The community-even those who did not necessarily support the women's stance-was determined to fight for maintaining their rules and norms. Notwithstanding this, after almost ten years of court cases and appeals, the Dutch High Court ruled in 2010 that the Dutch State was indeed in violation of Article 7 of the CEDAW. As a consequence, the Dutch State became obliged to take measures to ensure women's political participation within the SGP. An appeal by the SGP to the European Court for Human Rights was dismissed in 2012. The Dutch state, reluctant to interfere, gave the SGP six months to come up with their own solution (Vroegindeweij, 2012).

In March 2013, the SGP formally changed its women's stance. This, however, did not cause a norm change within the SGP community. The party changed its statutes, so women could no longer be formally refused, but it kept an informal manifest that signified that women's political participation is against their calling (SGP, 2013). In addition, the local SGP branches were not required to change their statutes accordingly, as these are largely independent from the national party.

Nevertheless, the grounds for maintaining the status quo were weakening. Both the informal pressure from the Dutch population at large, and the court cases instigated by the Dutch NGOs had an impact in shifting the bargaining resources (i.e., power) from the proponents of the women's stance to the more progressive members of the SGP community, like the Vlissingen branch.

\subsection{Enforcement}

The final step needed in order to understand the bargaining process is an appreciation of the role of norm enforcement. When the Vlissingen branch announced its election of Janse as their party leader, the SGP community could no longer use formal methods to block this. Informal disapproval, however, was immediately exercised. The Vlissingen branch received numerous phone calls, e-mails, and letters of disapproval (Respondent 7). These came from other local branches and conservative individual members. Most were polite requests for Janse to step down, as her role was not in line with a woman's calling (Lilian Janse, interview). The national SGP board visited the Vlissingen branch, to ask whether they would be willing to reconsider. The Vlissingen SGP members felt confident in defending their position, and emphasized the new formal rules: "I told them of course not! Everything happened legally, according to our regulations" (Respondent 7).

Janse's appointment as party leader met with strong social approval from outside the SGP community. Interviewed members of the Vlissingen branch report that people congratulated Janse on the streets, or promised her their support in the elections:

People approach me [and say]: 'Great that a woman is going to do it!' It is more about me being a woman of course. I get all kinds of positive comments about that. Outside the SGP community, actually only positive ones." (Lilian Janse, interview)

This external support made Janse feel that she was given "the status of heroine" (Lilian Janse, interview). Moreover, the approval was translated in votes during the city council elections, and resulted in the first political seat ever held by an SGP woman.

In summary, two elements seem to have jointly resulted in Janse winning her seat in the city council elections. First, the changing of the SGP's formal statutes, which happened after the Dutch authorities had lost the court cases initiated by the NGOs. This reinforced the second element, which was the strong informal enforcement. This informal enforcement came from widespread and strong support from the progressive Dutch majority. The media also reported on Janse very positively and the analysed newspaper articles seem to show a generally positive attitude towards her election. Second, there was also some support by the less conservative members within the SGP community.

Based on these qualitative findings, we argue that it was indeed a bargaining process over social norms that led to an increase in compliance. The conflict of interest within the SGP community over the women's stance was won by those in favour of changing it, due to their superior bargaining power. It is nevertheless too early to judge whether the norm change will be sustained. Even when some members of a community are convinced that a norm change is necessary, only continued informal support can guarantee long-term change. When such support is absent or insufficient, it remains likely that people will revert to honoring the old norm (Nee \& Ingram, 1998, p. 120). Only time will tell whether the norm change within the SGP can be sustained. Until then, our results only allow us to claim to have described the start of a possible norm change.

\section{Conclusion}

This study seeks to provide empirical evidence concerning the relationship between social norms and compli- 
ance with human rights treaties. Our quantitative findings show support for the proposition that social norms are positively associated with compliance to Article 7A of the CEDAW. The larger the adherence to conservative norms on women's political participation, the lower the state compliance with Article 7A of the CEDAW. This relationship between norms and compliance appears to be constant across countries.

Our complementary qualitative case study provides evidence that bargaining over social norms is one of the processes underlying the observed quantitative relationship. In this process, superiority in bargaining resources is essential. If the group with the most resources favours change towards less restrictive norms (i.e., the possibility of women's political engagement outside the household) then the resulting bargaining will lead to an increase in compliance with CEDAW's requirements regarding women's participation in politics. This study shows that such bargaining superiority is not only related to the community concerned, but can also be facilitated by groups outside the community. With outside support, even a minority within a community may win the bargaining process. This finding might be interesting for those who aim to implement human rights treaties in local communities that at first sight appear opposed to these treaties.

Our empirical findings suggest that social norms should be added to the explanatory factors of state compliance with human rights treaties. As such, our study confirms the propositions of previous studies that social norms can help explain the wide variation in compliance we see in practice (Cortell \& Davis, 2000; Fraser, 2019; Harris-Short, 2003; Zwart, 2012; Zwingel, 2012). They argue that compliance can be obstructed by populations when the content of a treaty does not match their social norms. On the other hand, populations can also support compliance when their norms match the content. Our study not only shows that such a relationship exists; it also explains why.

Even though the mixed-methods design provides a more thorough picture of the research subject than would have been possible by using only one method, time and space constraints do not allow us to use each method's potential to the fullest. A more elaborate qualitative study could lead to more detailed insights. For instance, this study sheds little light on the Dutch government's reluctance to interfere with SGP party matters, which might be related to a long tradition of protecting religious freedom. Finally, the qualitative part of this study increases the credibility that a causal relationship might exist between social norms and state compliance, as it identifies a process that underlies this relationship. Nonetheless, the relation might also work the other way around. The presence of women in politics could serve as an example, with the informal support of having more women in politics as a consequence.

This study establishes a first step towards a better understanding of the role of social norms in compliance with human rights. Challenges for future research lie in confirming, falsifying, and expanding the current results. Special attention could be paid to whether the bargaining process is also prevalent in other contexts, or why it might not be. The Netherlands is a typical example of a country with high compliance and a small share of conservatives. Additional typical cases, such as countries with low compliance and a large share of conservative people, could be researched.

\section{Acknowledgments}

All authors contributed equally to the article. In particular, we would like to thank our respondents for their openness and willingness to talk about our topic, and let us learn about their political standpoints and the norms they value deeply as a community.

\section{Conflict of Interests}

The authors declare no conflict of interests.

\section{References}

Abraham, E. (2003, July 13). Juridische bezemstelen [Legal broomsticks]. De Volkskrant. Retrieved from https://www.volkskrant.nl/nieuws-achtergrond/ juridische-bezemstelen $\sim$ b5591414

Acharya, A. (2004). How ideas spread: Whose norms matter? Norm localization and institutional change in Asian regionalism. International Organization, 58(2), 239-275.

An-Na'im, A. (2000). Human rights and Islamic identity in France and Uzbekistan: Mediation of the local and global. Human Rights Quarterly, 22, 906-941.

Bloomfield, A. (2015). Norm antipreneurs and theorizing resistance to normative change. Review of International Studies, 42(2), 310-333.

Boerefijn, C., \& Goldschmidt, J. E. (2007). Human rights in the polder: Human rights in the public and private sphere. Antwerp: Intersentia.

Cole, W. M. (2015). Mind the gap: State capacity and the implementation of human rights treaties. International Organization, 69(2), 405-441.

Cortell, A. P., \& Davis, J. W., Jr. (2000). Understanding the domestic impact of international norms: A research agenda. International Studies Review, 2(1), 65-87.

Dai, X. (2005). Why comply? The domestic constituency mechanism. International Organization, 59(2), 363-398.

Donnelly, J. (2007). The relative universality of human rights. Human Rights Quarterly, 29(2), 281-306.

Flowers, P. R. (2009). Refugees, women and weapons: International norm adoption and compliance in Japan. Stanford, CA: Stanford University Press.

Fraser, J. (2019). Challenging state-centricity and legalism: Promoting the role of social institutions in the domestic implementation of international human 
rights law. The International Journal of Human Rights, 23(6), 974-992.

Gërxhani, K. (2004). Tax evasion in transition: Outcome of an institutional clash? Testing Feige's conjecture in Albania. European Economic Review, 48(4), 729-745.

Government of Finland. (1996). Convention on the elimination of all forms for discrimination against women: Objections with regard to the reservations made by Kuwait upon accession. New York, NY: United Nations General Assembly. Retrieved from http://www. bayefsky.com/html/kuwait_t2_cedaw.php

Hafner-Burton, E., \& Tsutui, K. (2005). Human rights practices in a globalizing world: The paradox of empty promises. American Journal of Sociology, 110(5), 1373-1411.

Hafner-Burton, E., \& Tsutui, K. (2007). Justice lost! The failure of international human rights law to matter where needed most. Journal of Peace Research, 44(4), 407-425.

Harris-Short, S. (2003). International human rights law: Imperialist, inept and ineffective? Cultural relativism and the UN convention on the rights of the child. Human Rights Quarterly, 25(1), 130-181.

Hathaway, O. A. (2002). Do human rights treaties make a difference? Yale Law Journal, 111(8), 1935-2042.

Hathaway, O. A. (2007). Why do countries commit to human rights treaties? Journal of Conflict Resolution, 51(4), 588-621.

Helmke, G., \& Levitsky, S. (2004). Informal institutions and comparative politics: A research agenda. Perspectives on Politics, 2(4), 725-740.

Ibhawoh, B. (2000). Between culture and constitution: Evaluating the cultural legitimacy of human rights in the African state. Human Rights Quarterly, 22, 838-860.

Inglehart, R., Haerpfer, C., Moreno, A., Welzel, C., Kizilova, K., Diez-Medrano, J., . . . Puranen, B. (2014). World values survey: All rounds-Countrypooled datafile version. Madrid: JD Systems Institute. Retrieved from http://www.worldvaluessurvey.org/ WVSDocumentationWVL.jsp

King, G., Keohane, R., \& Verba, S. (1994). Designing social inquiry: Scientific inference in qualitative research. Princeton, NJ: Princeton Press.

Knight, J., \& Ensminger, J. (1998). Conflict over changing social norms: Bargaining, ideology, and enforcement. In M. C. Brinton \& V. Nee (Eds.), The new institutionalism in sociology (pp. 105-126). Stanford, CA: Stanford University Press.

Lebovic, J. H., \& Voeten, E. (2009). The cost of shame: In- ternational organizations and foreign aid in the punishing of human rights violators. Journal of Peace Research, 45(1), 79-97.

Merry, S. E. (2009). Human rights and gender violence: Translating international law into local justice. London and Chicago, IL: The University of Chicago Press.

Moon, S., \& Hein, W. (2013). Informal norms in global governance: Human rights, intellectual property rules and access to medicines. Farnham: Ashgate.

Nee, V., \& Ingram, P. (1998). Embeddedness and beyond: Institutions, exchange and social structure. In M. C. Brinton \& V. Nee (Eds.), The new institutionalism in sociology (pp. 20-44). Stanford, CA: Stanford University Press.

Nyamu-Musembi, C. (2002). Towards an actor-oriented perspective on human rights (Working Paper No. 169). Brighton: Institute of Development Studies.

Oomen, B. M., Guijt, J., \& Ploeg, M. (2010). CEDAW, the bible and the state of the Netherlands: The struggle over orthodox women's political participation and their responses. Utrecht Law Review, 6(2), 158-174.

SGP. (2013). Program van beginselen [Programme of principles]. Rotterdam: SGP. Retrieved from https:// www.sgp.nl/partij/huisstijldownloads?category $=4$

Simmons, B. A. (2009). Mobilizing for human rights. Cambridge: Cambridge University Press.

United Nations General Assembly. (1979). Convention on the elimination of all forms for discrimination against women (Resolution 34/180 of 18 December 1979). New York, NY: United Nations General Assembly. Retrieved from https://www.ohchr.org/en/ professionalinterest/pages/cedaw.aspx

Vroegindeweij, G. (2012, November 29). Van Leeuwen (SGP): Uitspraak Hoge Raad is geldend recht [Van Leeuwen (SGP): Supreme court ruling is applicable law]. Reformatisch Dagblad. Retrieved from https:// www.rd.nl/vandaag/politiek/van-leeuwen-sgpuitspraak-hoge-raad-is-geldend-recht-1.703854

Welzel, C. (2002). Effective democracy, mass culture, and the quality of elites: The human development perspective. International Journal of Comparative Sociology, 43(3/5), 317-349.

Zwart, T. (2012). Using local culture to further the implementation of international human rights: The receptor approach. Human Rights Quarterly, 34(2), 546-569.

Zwingel, S. (2012). How do norms travel? Theorizing international women's rights in transnational perspective. International Studies Quarterly, 56(1), 115-129.

\section{About the Authors}

Violet Benneker works as Advisor on Political Dialogue in fragile and conflict-affected settings for a non-governmental organization. In addition, she is PhD candidate at the Institute of Political Science, Leiden University, the Netherlands. Her main expertise lies in the field of social norms and political dialogue, including political dialogue about contested human rights. Her research is mixed-methods and interdisciplinary, combining quantitative with qualitative methods, and bringing together insights from political science, international relations, and sociology. 
Klarita Gërxhani is Professor of (Micro)Economic Sociology at the European University Institute, Florence, Italy. She received her PhD in Economics at the Tinbergen Institute and the Faculty of Economics and Business, University of Amsterdam. Her main expertise lies in the micro-foundations of economic sociology. Her research is interdisciplinary, combining laboratory and field experiments with field surveys and economic-sociological theory. She is the author of various articles published in internationally peer-reviewed journals, including the Annual Review of Sociology, Social Networks, PloS ONE, European Sociological Review, European Economic Review, Experimental Economics, Social Science Research, Journal of Institutional Economics, Journal of Economic Psychology, and European Journal of Political Economy.

Stephanie Steinmetz is an Associate Professor of Social Stratification at the University of Lausanne, Switzerland, where she is a member of the Life Course and Inequality Centre (LINES) and collaborates closely with FORS. She is also an affiliated researcher at the University of Amsterdam where she works with the Wagelndicator Foundation on topics related to survey methodology. She is part of the executive committee of the InRID2 project. Her main research focuses on vulnerable groups in education and the labour market from a cross-national perspective and the role of institutions in shaping cross-national differences. Her work has been published in internationally peer-reviewed journals, including the European Sociological Review, Comparative Social Research, the International Journal of Comparative Sociology and Social Politics. 